\title{
SALENG ABENTHO: A STRATEGY TO REDUCE COSTS OF LOCAL RESOURCES-BASED MADURESE CORN FARMING
}

\author{
Hisnuddin Lubis ${ }^{1 *}$, Nely Rohmatillah ${ }^{2}$ \\ 1 Universitas Trunojoyo Madura, Indonesia \\ ${ }^{2}$ Institut Agama Islam Qomaruddin Gresik, Indonesia \\ *e-mail: hisnuddin.lubis@trunojoyo.ac.id
}

\begin{abstract}
Madurese corn is one of the leading agricultural commodities of Madura. Its opportunity is quite prospective, given that the national corn-based industry shows a positive trend from year to year. The problem is that the corn cultivation by the Madurese people is merely oriented to serving the purpose of meeting food needs rather than a profit-oriented one. This is because the planting costs are relatively expensive with a thin profit margin. Therefore, a cost-efficient strategy for local resources-based Madurese Corn Farming is required. The present study is expected to produce a strategic model for using local resources to reduce the costs of Madurese corn farming. This study was carried out in Gapurana Village, Kalianget Sub-district of Sumenep Regency Madura, using the qualitative descriptive approach. Data were collected by observation and in-depth interviews and analyzed using the Mils and Huberman model. The results showed that local resources, especially social resources in the form of solidarity 'saleng abentho', effectively reduced the costs of Madurese corn farming. This resource could be managed and institutionalized by involving farmer groups and policies to realize an industrial-scale Madurese Corn Farming.
\end{abstract}

Keywords: Cost Strategy; Corn Farmers; Social Resources; Madura Corn

This is an open access article under the $\underline{C C B Y-S A}$ license.

Copyright $@ 2021$ by Author. Published by Universitas Pendidikan Ganesha.

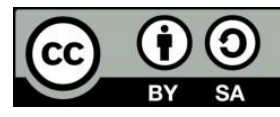

\section{INTRODUCTION}

The agricultural sector is one of the most contributing sectors to the national economy. Job creation, fulfillment of food and national industrial needs, income from taxes and exports constitute the significant roles of agriculture in the national economy. Employment in the agricultural sector is populist, due to its rural and peripheral locality, and is labor intensive. Adequacy of employment opportunities in rural and peripheral areas can directly or indirectly help to solve urbanization which is considered an urban problem (Fauziyah et al. 2010) One of farmer's most popular agricultural products (food) after rice is Corn (Zea mays) is among the agricultural crops with an economic value and opportunity to be developed for both consumption and industry. Nationally, corn is mostly used as the main raw material for the animal feed industry, amounting to 51 percent. This is followed by its use as a food ingredient, including ready-to-eat food, corn flour, vegetable oil raw materials, and snacks, Corn has the largest carbohydrate and protein content after rice, so it is often used by people as an alternative staple food to rice. It can also be used as a natural sweetener and is frequently used by industries. Therefore, in terms of both consumptive and industrial use, corn continues to increase in demand (Zakaria 2011; Suryana and Agustian 2014; Mink and Dorosh 2019).

Corn plants are used by people not only for the fruit. The young corn leaves and stalks are used by people as animal 
feed. Dry corn leaves and stalks are used as material for compost and partly for fumigation of cows and some are used as alternatives for paper-making. Meanwhile, the young corn fruit can often be used as a cooking ingredient, such as vegetables and fried foods. Meanwhile, corn can also be used as raw material for the pharmaceutical, animal feed and other industries (Purwanto 2007).

Until recently, the opportunity for corn farming in Indonesia is quite promising. A study by (Suryana and Agustian 2014) concluded that corn farming in Indonesia remained quite potential to generate profits for farmers. Furthermore, the average farmer gained a financial benefit of IDR $6,700,000 / \mathrm{Ha}$ with an $\mathrm{R} / \mathrm{C}$ ratio of 1.73 . Meanwhile, the corn farming was economically more profitable than its financial value. Farmers would gain an economic benefit of IDR $8,700,000 / \mathrm{Ha}$ with an $\mathrm{R} / \mathrm{C}$ ratio of 1.90. Nationally, corn farming also has good competitiveness and both financial and economic efficiency. Corn farming has a DRCR coefficient of 0.48 and a PCR of 0.54 nationally.

The potential use of corn Farming in Indonesia should be developed and facilitated by the government. Agricultural development policies are highly required in order to optimize the opportunities and potential of the corn crop to increase the State and farmers' incomes through corn farming. One of the agricultural development policies for the production and income of farmers is through the five efforts called Panca Yasa, namely: 1) Improvement of agricultural infrastructure, including construction, rehabilitation, irrigation, road access, and others; 2) Agricultural institutional strengthening, including the establishment and revitalization of farmer groups, Gapoktan (association of farmer groups), farmer associations, P3A, and cooperatives; 3 ) counseling and implementation of agricultural technology, including building the capacity of counselors, recruiting counselors, and others; 4) capital assistance, namely loan guarantees, interest subsidies, KKP, SP3, BLMKIP, and others; 5) improving the Marketing of Agricultural Products, including setting the government purchase price (HPP), improving the quality of products, and others.

The Panca Yasa agricultural policy requires at least a synergistic collaboration between the government and the community with all their resources. Communities can take advantage of local resources which are indigenous, meaning they are natural, rather than artificial, and are not the result of fabrication (Warren, in Santosa 2014).

The implementation of the Panca Yasa agricultural policy is represented in the strategies of increasing productivity, expanding the area, securing production, institutionalization, and financing. Those strategies involve the use of material, human and social resources. The relevant strategic efforts in the present study are ones to strengthen Agricultural institutions and financing, where those efforts involve empowerment strategies and mobilization of social and financial resources (Purwanto 2007).

Since corn is highly compatible with dry land ecology, such as in Madura, it is not surprising that it is the crop planted by the majority of Madurese people, especially in eastern Madura. Unfortunately, however, corn planting by the Madurese communities is merely oriented to meeting food needs, rather than for industry (Hefni 2008). This is understandable since the economic value of the local Madurese Corn is lower than that of the new Corn varieties. According to (Sugiarti and Hayati 2009), Madurese farmers remained maintaining local Corn varieties, despite the development and introduction of new Corn varieties. So far, Madurese farmers remained resistant to new Corn varieties and thought that it was better to plant local Corn varieties. This was because growing corn was only to meet family consumption needs. In addition, Madurese farmers thought that local Corn was easier to cultivate. Meanwhile, in terms of cost efficiency, (Fahriyah and Salma 2012) argued that the corn farmers in Bangkalan Madura have not yet reached the cost-efficient 
level. (Suprapti et al. 2014) found that the corn farming was not economically efficient despite the allocative efficiency. Therefore, other efforts are required to increase corn farming efficiency.

The Problems not only occur in Madura, development of agriculture in the context of tourism in Bali also cannot be separated from the problems that hinder it. (Parma 2014)in his research found that the weakness of social institutions in the Kintamani community was caused by the forming orientation and activities of farmer groups that were incidental, only to distribute the government assistance and programs. The low participation and cohesiveness of members, individualism in the management of productive activities, and the most influential is, the institutional formation is not based on local social capital that in the principal of local independent. Such problems are also found in agriculture in Madura, where institutional weakness is the dominant factor in agricultural problems.

Therefore, it is necessary to reorient Madurese Corn cultivation from meeting food needs to meeting industrial needs to increase the income of Madurese corn farmers. Indeed, these efforts should be accompanied by socialization, counseling, and training by mobilizing various available resources. In the logic of empowerment, these efforts involve increasing the knowledge capacity, Attitude and Practice of the local community.

The economic opportunities for corn in Madura can be optimized if the community is aware of its potential. In the perspective of agricultural development, the community should be the main subject of development. This means that the community should actively participate in development, including initiation and sensitivity in identifying self-potential in the form of local wisdom/local resources. In order to maximize the utilization of the potential of local wisdom, the community should have the ability to identify the potential around them, positive attitudes and responses to these resources (Soetomo 2014). In the perspective of the Socio-ecological System (SES), an actor is needed as the driving force in resource utilization. Actors need social institutions and substances used as "bargaining power" in natural resource management. This concept is known as Actor Base Models in SES. This model is considered necessary along with ecological problems as a result of social dynamics such as land narrowing, pollution, reduced land productivity, and so on (Rounsevell, Robinson and Murray-Rust 2012; Filatova et al. 2013). This development model is expected not only to increase the quantity of development so that farmers are more empowered by involving development agents and synergies with local resources of the farmers' community (Aminah, Lubis and Susanto 2015).

Utilization of resources to solve community problems is considered highly effective, efficient and targeted. Its success and sustainability that support productive, creative and innovative businesses are more guaranteed (Santosa 2014). The advantages of this strategy can be described as following Figure 1.

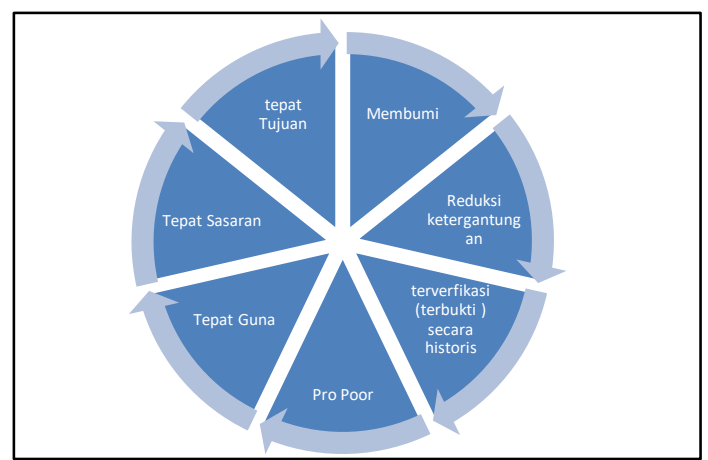

Figure 1. The Advantages of the utilization of the potential of local wisdom

In line with that, the agricultural industry (Poland) shows that the effectiveness of production costs to increase profits is more influenced by the relationship of intangible resources than the relationship between the level of labor, size and quality of land. These intangible resources include relational capital, technological resources, knowhow and managerial capabilities of farmers (Matyja 2016). 
In the context of Madura, the problem faced is low productivity. The study results show that $35 \%$ of Madura farmers have not been able to produce efficiently (Yusli and Fauziyah 2020). From the agribusiness side, the problems of Madura corn farmers can be identified based on research by (Ratna 2011) which are productivity, institutional, and household-scale business development problems . Another problem of Madura corn farming economically is the high price of production inputs such as seeds and fertilizers, which continually increase the price when entering the planting season (Firdaus and Fauziyah 2020). Meanwhile, (Suprapti, Isdiana, Dwidjono Hadi Darwanto 2014) revealed that Madura Corn production efficiency is still relatively low. This is influenced by experience in Corn farming and technical factors. Previous research shows that there has been no effort to utilize social resources to overcome the problems of corn farming in Madura.

The problem of corn farming is simply how social resources can be utilized to minimize the cost so as to increase corn economic value. Therefore, a driving force is needed to motivate human action. These forces, either directly or indirectly, lead to changes in the ecosystem, both reducing and increasing productivity. This understanding provides an opportunity for choices for actors to determine motivational actions, including, for example, based on local knowledge in the community (Petrosillo et al., 2015).

Communities in general have localities in the form of human, social, economic, technological, and natural resources. Sociologically, these resources can be used in agricultural activities to reduce agricultural "production" costs, especially social resources. By utilizing the potential of local resources, corn farming costs can be minimized so that profits would be higher. The author was interested in invertigating the social resources of the Madurese corn farming community that are potential for use to reduce the costs of Madurese corn farming. Thus, social resources can be used as a starting point for the use of other local resources. The problem that motivated the present study was to examine strategies to reduce the social resources-based Madurese corn farming costs in Talango of Sumenep Regency. Corn farming costs include the cost of working the land (pre-planting to post-harvest). By identifying and understanding potential local resources, strategies can be formulated to reduce the costs of Madurese corn farming so as to increase motivation and income of Madurese Corn farmers. Therefore, the present study is very important, given that this would be one of the solutions to reduce the costs of Madurese corn farming. In the long term the community is expected to make corn their source of income.

Agricultural development is an integrative form of increasing social welfare (material) and the environment. This process is not simple, but the complexity of the roles of various stakeholders, not only the modernization of agriculture, but how to accelerate the growth of agricultural productivity which is accompanied by the growth of other sectors. In addition, agricultural development must also offer appreciation and recognition of local wisdom, resource management with locality, especially in developing countries (Udemezue and Osegbue 2018).

The present study examined the strategy to reduce the costs of Madurese corn farming by utilizing local resources, especially social resources. Corn farming costs include the cost of working the land (pre-planting to post-harvest). By identifying and understanding potential local resources, strategies can be formulated to reduce the costs of Madurese corn farming so as to increase motivation and income of Madurese Corn farmers. Therefore, the present study is crucial, given that it would be one of the solutions to reduce the costs of Madurese corn farming The findings of this study are expected to be an input for agricultural policies, especially in Madura. This effort to reduce agricultural production costs is in accordance with the business logic of 
agricultural companies, where the basic competitive strategy is to reduce production costs in addition to differentiation of competitive advantage (Kasem and Thapa 2012). Meanwhile (Micheels and Nolan 2016) added that one of the strong factors is social capital, especially social relations in society, relationships with companies, social organizations, knowledge networks, and absorptive capacity. By the various agricultural development models (Frontier model, conservation model, the Urban-Industrial Impact Model, The High Payoff Input Model, the Diffusion Model) there is one model that is relevant to the characteristics of agriculture in Madura. Where the model emphasizes the intensification process by prioritizing labor-intensive planting systems, the production and use of organic fertilizers, and the formation of labor-intensive capital from the community. This model is often referred to as the conservation agricultural development model (Udemezue and Osegbue 2018).

The utilization of local resources in agriculture requires integration in the management and adjustment of environmental conditions. In this context, the research will use the Socio-Ecological System (SES) analysis framework. This SES framework has been developed in such a way as to analyze its "Humanenvironment" dynamics. The role of SES in this context is to answer how the value system can be utilized to create resilience from the impact of social dynamics (Cote and Nightingale 2012). Meanwhile(CioffiRevilla 2016) study in the perspective of social computing shows some basic frameworks in SES that the function of human adaptation as an integrated framework will result in sustainability. Sustainability will be achieved by a resource-efficient strategy and independent of the Series program and optimizes coordinated parallel efforts. According to him, to create sustainability, there must be collective action to manage, develop and elaborate the "human and artificial ecology" system in a resource-efficient manner.
Parker et al., 2008 cited in (Tatiana Filatova et al. 2013) explain how to connect between components in SES. According to him, there are three approaches in connecting between components in SES. The first is a oneway relationship, namely when natural science (Ecology) becomes the input for the social system. The two links are a one-way relationship with the Natural social - natural model input and produce a Natural System Output, and the third is a two-way relationship by determining the determinant indicators in both the Natural System model and the social system through the interaction between the natural environmental system and the social system. For example, decisions to harvest wood depend on carbon storage and climate change. Climate change and carbon deposits are affected by the changing climate as a result of logging. This means then that harvest decisions (social systems) interact in influence with the natural environment.

SES in many studies is often used to look at resilience and sustainability in various focuses, such as agriculture, by utilizing local wisdom, institutions, and indicators of the assessment of sustainability aspects of a problem (Budiarti and Muflikhati 2013; Maleksaeidi and Karami 2013; Domptail and Easdale 2013; Sterk, Leemput and Peeters 2017). SES can be broken down in terms of the social, economic, ecological, cultural, political, and technological components related and integrated into a "Human-in-Nature" perspective. An example is the traditional agricultural landscape shaped by the interaction and co-evolution over centuries of society with nature. Various rural communities in Japan, China, India, and Europe are characterized by traditional ecological knowledge systems managing natural ecosystems. However, along with the social dynamics of the traditional ecological system, it began to get pressure from social changes, industry, infrastructure development. This condition causes agriculture to be no longer profitable and requires integrative thinking such as agricultural 
intensification, local resources, and so on (Petrosillo, Aretano and Zurlini 2015) In this study, the decision to utilize social resources (the saleng abentho system) is an accumulation of the interaction relationship between the ecology of the Madura moor and the social system that has existed for a long time.

SES can be understood as an interdependent study between social systems and ecological systems and linked. According to (Berkes and Folke 1994) the views of social systems and ecological systems have not been entirely accepted in conventional social and ecological sciences. This SES study also considers how locality, specifically Indigenous knowledge (IK), shows unique local knowledge. SES presupposes the existence of linkages between ecological systems and social systems. The next awareness is that the ecological system influences humans to manage nature for the benefit of humans with all the social resources they have (Berkes and Folke 1994) Social dynamics demands awareness of the environment, environmental damage resulting from social processes requires further studies in the use of integrated natural resources in social systems (Sterk, Leemput and Peeters, 2017)

With the ecology of the moor, Madura encourages the Madurese to choose the appropriate types of plants. In Madura, 3 Tegal plants were chosen by the community as a form of local knowledge. These three crops are grown on a rotational system, namely corn, rice, and tobacco. Corn is one of the most important crops and is used as a staple food other than rice, especially in eastern Madura (Hefni 2008). This way of planting Madurese corn can be understood as an interdependent relationship between the social system and the ecological system, which is the focus of the SES study.

\section{METHODS}

The present study used the qualitative method in a case-study approach framework based on the reflective aspects. This study model designed to explore the subjects' interpretations based on field facts. This shows the urgency of the researcher's role in observation, data collection, and interpretation. In the end the researcher is expected to have the sensitivity to distinguish reality. A Qualitative study places an emphasis on an understanding (verstehen) in making a sense of and linterpretation of an event in their study(Usman and Akbar 2008)

A case study is one of the qualitative approaches which examines a case considered important in the setting of the reality of life. The case study approach in the present study focused on a single important issue of the strategy to reduce the costs of local resourcesbased Madurese corn farming (Creswell, 2017). It can be categorized as a single case study with a single level of analysis since it assesses a group of individuals with one important issue. (Salim 2006)The scope of the present study was to examine the strategy of reducing the costs of Madurese corn farming by utilizing local resources, especially the most potential social resources.

Data in the present study consisted of primary and secondary data. Primary data are data obtained directly from the field and the researcher's testimonies, which are recorded and documented while in the field. Secondary data are data gereated from outside the field that may include publications related to the focus of the study, research reports, agency data, and the like. Data were collected by observation and interviews.

Observation began with the identification of information required in the focus of study and observation of the study location, Talango Sub-district of Sumenep Regency. The present study used the non-participant observation. During the observation, the researcher was guided by field assistants who were familiar with the study location. The targets of observation were corn farming land, corn field tilling, planting processes (when coinciding with the growing season), and community activities outside the field considered as supporting the identification of social resources and other matters deemed necessary. 
An interview is a data collection technique using questions adapted to the study conceptual framework. It is a verbal question and answer between two people called the interviewer and the interviewee. To facilitate interviews, the researcher used the previously prepared interview guides. One of the advantages of the interview method is that the information obtained is more comprehensive and across time. This means that it relates to the past and present and informants' views about the future (Burhan 2007). The interviews were conducted in a natural setting, meaning that they were conducted in the fields during their work break. In this situation, farmers were more natural in answering the researcher's questions.

Data analysis includes the stages of data reduction, data presentation, and conclusion drawing. During the analysis, the role of the researcher's interpretation based on the theoretical perspective is very important along with descriptive narrative writing so that a conclusion can be drawn. In the qualitative research tradition, the researcher usually collects, reduces, and presents data simultaneously in a format in accordance with the narrative flow until it represents a complete description. Meanwhile, the researcher will test the validity of the data using the data triangulation method. Data triangulation is a mechanism for checking the validity of data by utilizing external sources both methodologically and from different sources (Moleong, 2000). This mechanism was performed in stages: (1) data were collected through several sources, including observation, in-depth interviews, and document analysis; (2) systematic and structured observations in the study location.

\section{RESULTS AND DISCUSSION Corn Farming in Gapurana Village: Saleng Abentho vs Individual System}

Corn farming in Gapurana Village was carried out from generation to generation and has been an annual routine job. Almost all the people of Gapurana Village had their own dry field, but it did not mean that they grew corn individually or only for family purposes. Rather, they grew Corn by means of a mutual cooperation system or together with neighbors or other communities by taking turns from one dry field to another. Tradition in this kind of community represents solidarity and gotong royong, which is one of the characteristics of rural communities in Indonesia. The gotongroyong system is widely applied in various sectors of community life. For example, celebrations, deaths, village clean-ups, and some Madurese communities apply them in the agricultural system. This system is part of local wisdom. This system was later referred to as Saleng Abentho. This planting system is carried out out of habit, a form of solidarity in society. The work system in this model is based on the principle of mutual assistance.

Some critical notes in Madura corn farming using this system are: First, this system is the original local wisdom of the Gapurana Madura community. This community-based cropping system has been practiced for a long time but has not been formally institutionalized like the government-established farmer groups. Second, about the socio-ecological system, this corn planting system adapts to the environment. Referring to (Hefni 2008) that the Madurese community chooses three types of plants to plant with the characteristics of the moor. This can be described as following Figure 2 .

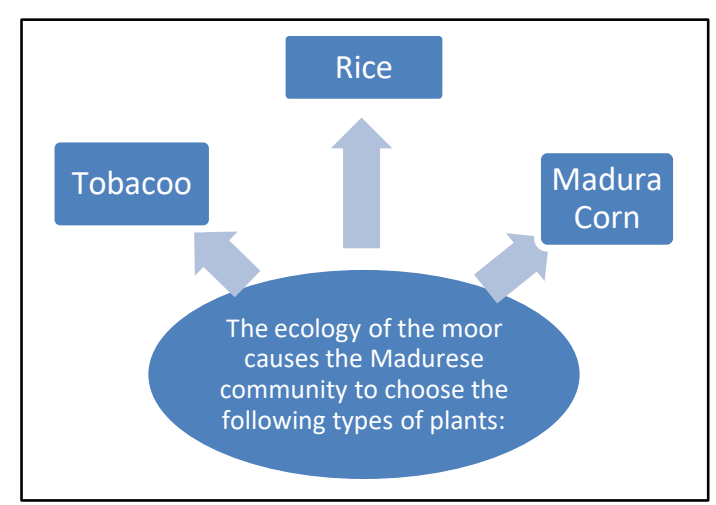

Figure 2. Commodity Selection based on Moor ecology

Source: extracted from (Hefni, 2008)

Third, the use of local wisdom of saleng abentho in Madura corn farming is 
a form of adaptation to dry conditions that are increasingly experiencing a decline in productivity. This can be seen from the low economic efficiency of Madura corn cultivation based on studies from (Ratna 2011; Suprapti et al. 2014; Yusli and Fauziyah 2020). The narrowing of land reduced soil fertility has implications for the decline in agricultural yields of Madura corn. This condition is exacerbated by the high cost of Madura Corn farming inputs (the price of seeds, fertilizers, labor costs). This problem (if observed from the point of view of SES) is an accumulation of Ecological - Social-ecological conditions that require the community to adapt to these conditions.
Cote and Nightingale (2012), emphasizes the use of valuable resources in society to create socialenvironmental resilience. This utilization is an integrative effort of the management model with the environment. This planting system is also seen in the Madurese community in the Madurese corn planting system called the Saleng Abentho System. Utilization of this valuable resource is proven to preserve (create resilience) Madurese corn farmers, even though they are faced with both ecological and sociological problems. Meanwhile, when viewed from a different point of view, the use of values and solidarity is an adaptation function in collective action.

Table 1. Average expenditure of corn farmers during the growing season with the 'saleng abentho' system

\begin{tabular}{lccc}
\hline \multicolumn{1}{c}{ EXPENDITURE } & UNIT & PRICE & TOTAL \\
\hline Meal & 20 & 4,000 & 80,000 \\
\hline Coffee and snacks & 20 & & 40,000 \\
\hline Fertilizers & 3 & 100,000 & 300,000 \\
\hline Cigarettes & 10 & 7,000 & 70,000 \\
\hline $\begin{array}{l}\text { Other (corn care) } \\
\begin{array}{l}\text { Hybrid seed (if } \\
\text { required) }\end{array}\end{array}$ & 10 & 20,000 & 200,000 \\
\hline & $1 \mathrm{~kg}$ & 70,0000 & 70,000 \\
\hline
\end{tabular}

Table 2. Average expenditure of corn farmers using the individual system

\begin{tabular}{lcrr}
\hline \multicolumn{1}{c}{ EXPENDITURE } & UNIT & \multicolumn{1}{c}{ PRICE } & \multicolumn{1}{c}{ TOTAL } \\
\hline Meal & 20 & 4,000 & 80,000 \\
\hline Coffee and snacks & 20 & 4,000 & 80,000 \\
\hline Fertilizers & 3 & 150,000 & 450,000 \\
\hline Cigarettes & 10 & 7,000 & 70,000 \\
\hline Corn care & 20 & 20,000 & 400,000 \\
\hline Tillage cost & 2 & $100,000(1 / 2$ day $)$ & 200,000 \\
\hline Planting costs & 2 & 150,000 & 300,000 \\
\hline Local seed & $3 \mathrm{~kg}$ & $40,000 / 3 \mathrm{~kg}$ & 40,000 \\
\hline Hybrid cost & $1 \mathrm{~kg}$ & 70,000 & 70,000 \\
\hline Total & IDR $1,690,000$ & & \\
\hline
\end{tabular}

The strategy to reduce social resources-based Madurese corn farming costs in Talango Sub-district of Sumenep Regency can minimize the costs incurred by the farmers with social capital (mutual cooperation) As research result of (Micheels and Nolan 2016). It can be an important alternative to create profitable farming for farmers. Rhus far, farming was only an unprofitable means of making a living. Results of the present study showed that the corn farming practiced by the farmers of Gapurana Village, describes a very modern and civilized agricultural process. This was because they were able to establish cooperation among individuals and the groups to work communally. There was no competition that caused each other to defeat fellow farmers, but they worked together to produce adequate yields. They did not only get good farming yields and processes, but taught the meaning of togetherness. 
With togetherness, everything would be easy to do and achieve. The philosophy they adopted on a daily basis is "it is better to have a work debt than to owe money". During the process of planting, each farmer family only spent costs for consumption. From the perspective of the Socio-Ecological System (SES), the implementation of the Saleng Abentho system is part of the unique Indigenous Knowledge (IK) of the Gapurana Madura community. The practice of working in groups with zero labor costs will ultimately be mutually beneficial to the community. The ecological condition of the Madura moor provides awareness to the community on how to manage its ecology with the social resources it has(Berkes and Folke 1994).

SES, dimensionally in it there are values, meanings, identities and local ecological knowledge and practice as a whole Mutual cooperation in farming communities can be observed in various livelihoods. During the process of working on agricultural land, the farmers required labor for tilling the land, sowing seeds and planting, regulating irrigation, fertilizing and weeding crops. The series of farming activities were generally performed by mutual cooperation in rotation to reduce costs relative to hiring agricultural laborers. This mutual cooperation was also practiced when the harvest time arrived. The community picked the agricultural products, dried them, and put them in the barn in mutual cooperation as well (Poe et al., 2014).

As rhe Resul of (Micheels and Nolan 2016) The values of mutual cooperation were strongly instilled in rural communities, especially in villages of Talango Sub-district of Sumenep Regency. This behavior has existed from generation to generation. In the perspective of community development, local resource in the form of the mutual cooperation system of 'saleng abentho' represents a part of indigenous local which, according to (Warren ([1991] in (Santosa 2014), is often referred to by communities in performing their activities, including agriculture from generation to generation.

We can also understand this system as an accumulation of experience, observations of the community in their interaction with the ecology of the moor from time to time. The cumulative results are represented in a social value system used in the management of the agricultural Ecological Environment (Minah et al. 2019) Refers to SES where the sustainability of this management is based on saving resources, does not depend on series programs from the government, prioritizes coordinated and collective action (Cioffi-Revilla 2016).

In principle, this mutual cooperation is interpreted by the local community as 'saleng abentho e musim ghure'. Even though it was not officially organized, it departed from a sense of

Jurnal IImu Sosial dan Humaniora | 495 
concern, awareness and a high level of solidarity. It has existed since the communities have been familiar with the corn farming system. The 'aghure' process with the 'saleng abhento' system includes:

1) People who are ready to plant or those who have cows or those who have a lot of land will first start the process of sowing manure. This is usually done by women.

2) The neighbors are invited or even come to the land owner to take part in sowing manure. And those who help this will be treated the same when their land will be cultivated.

3) After all of the land (combined community land) is sowed with manure, the next process is 'anangghele' or plowing started by the cow owner. This is usually done by men.

4) After all of the land (combined community land) has been ploughed, the next process is to wait for the rain at least three times.

5) Subsequently, the owner of the cows will start 'aghure' or plant corn and the neighbors will directly help the owner of the livestock and then it turns to other neighbors who are ready to plant their land. This is done jointly by both men and women.

6) Before the corn grows, the people who are members of the village agricultural group will offer their assistance to other neighbors who have not joined, so that they can get access to fertilizers during the corn planting period.

7) After the corn grows and has three leaves, it should be given urea fertilizer and this is usually done independently by each family.

8) When the corn field is overgrown with weeds, the women start to be active again to form a 'Sosso'an' group or a group of women who will clear one land to another from weeds. This is done until the corn is approximately 60 days old.

9) After the corn is ready for harvest, the people who are members of a group at the beginning of the corn farming process do the corn harvest together, calculate the crop yields and put the corn in the barn. All of the processes are done voluntarily and the land owners only provide the meal.

SES in the agricultural sector needs the role, participation, and collective awareness of the community and mobilization of social/local resources in order to utilize the most of it for agricultural development. This strategy can be undertaken by optimizing and revitalizing the role of local institutions, such as farmer groups, in order to increase farmer participation, capacity and efforts to utilize social resources by utilizing farmer groups (Krisnawati 2014).

Efforts to increase agricultural yields are not adequate with the Jurnal IImu Sosial dan Humaniora | 496 
application of sophisticated technology that potentially creates alienation for local communities. The agricultural sector should be given the opportunity to develop agricultural land properly. This requires policy makers' commitment and participation and community participation in synergy to advance the agricultural sector. This is where the social-ecological system proceeds to realize the linkages of the socialecological system (Velasco-Fernández 2017), The corn farming practiced by the corn farmers in Gapurana Village involves a process that can be used as a model or strategy to advance agriculture, namely mutual cooperation. There are several farming processes that can be done in a mutual cooperation, so that communities and the nation can provide adequate food for the common interests.

Food independence can be achieved by making agriculture the main basis in fulfilling the primary needs of the community. The agricultural sector is often regarded as the leading sector supporting the national economy in an agricultural country like Indonesia. Agricultural development in Indonesia is considered highly important in the framework of national development. In Indonesia it can be realized by extensification or intensification approaches. The use of idle land and the application of new technology in agriculture should not result in an alienation in the use of social resources and local wisdom of the Indonesian people. Sociologically, Indonesian people have a variety of potential local wisdoms that can be utilized as a 'cultural capital' in agricultural development (Micheels and Nolan 2016) Utilization of local (social) resources in the form of 'saleng abentho' in Gapurana Village of Sumenep Regency constitutes a local wisdom that can increase the cost efficiency of Madurese corn farming. This is in line with the findings of (Hijjang, Lampe and Basir 2014), stating that local knowledge in farming communities in South Sulawesi is also used in agricultural activities starting from determining the season, selecting seeds to postharvesting (Micheels and Nolan 2016; Udemezue and Osegbue 2018). The principle of increasing profits in agriculture in this context is achieved by utilizing local resources. The goal to be achieved is to maximize profits by minimizing costs

It is different from agriculture which has adopted modern technology as in developed countries. In this context, agricultural development prioritizes the use of technology. As research conducted by (Rovira-Más, Chatterjee and Sáiz-Rubio 2015), that the promotion of sustainable food production, especially in Japan, Europe and North America is through robotization technology, although it still encounters some technical obstacles in the field. This study tries to use the Jurnal IImu Sosial dan Humaniora | 497 
GNSS (Global Navigation Satellite Systems) model for the effectiveness of agricultural robot technology. Meanwhile (Sheng et al. 2015) concluded that small-scale farmers who cannot do extension can only develop agriculture through the adoption of advanced technology. Madura corn farming is still traditional, the land is narrow, the dissemination of technology is still very limited. Therefore, the potential for agricultural development is more emphasized on the use of local social resources such as corn farmers in this Gapurana village

\section{The Role of Government Policy}

Government policy is one of the mechanisms for utilizing potential and overcoming problems in state life. In a broad sense, policy can be understood as whatever government choose to do or not to do in response to the realities in society. Specifically, government policy can be interpreted as a positive response to solving problems and utilizing the existing potential. Friedrik defines a policy as a series of actions proposed by a person, group or government in a particular setting under the existing threats and opportunities. The proposed policy is to exploit the potential as well as overcoming obstacles in order to achieve common goals (Suharto 2009)

In this sense, the government policies constitute a means to cope with problems by utilizing its potential. Madurese Corn is a potential that requires a policy for utilization to the greatest extent possible by the community. The problem is to determine the efforts to make it happen, one of which is through some policies that support this potential. For an agricultural country like Indonesia, the agricultural sector requires policies (Kasem and Thapa 2012). (Todaro and Smith 2000) argues that agricultural advancement can be realized quickly when there are technological innovation, populist government policies, and supporting social institutions. In the context of the Gapurana community, social institutions have the dominant power in driving social activities, including corn farming, which in the local term is called 'saleng abentho'.

Utilization of local social resources is expected to bring about empowerment and independence of Madurese corn farmers, without dependence on technology and government assistance to create welfare in empowerment. Such efforts are believed to be sustainable and effective since a community should be able to map out their potential and use it for the common interests. Thus, this agricultural development model represents a form of development that respects locality (local wisdom, culture, resources, skills, technology, and processes). Interactions among these localities will be manifested in both material and social resources (Ife and Tesoriero 2008). For example, in supporting the practice of this development model, the Jurnal IImu Sosial dan Humaniora | 498 
government issued Law of the Republic of Indonesia Number 19 of 2013 concerning Protection and Empowerment of Farmers. Important points in the law are institutional redefinition in agriculture, accommodation of locality values, protection of farmers, strengthening of institutions, agricultural facilities and infrastructure as well as subsidies for farmers (Indonesia n.d.) .

A social institution can be perceived as a system of norms and relationships that integrate values and procedures that apply in social life to meet the basic needs of community members. In this context, the Gapurana people have a social institution which in another perspective can be identified as a local resource, especially social resource. This resource, as described above, is a strong solidarity in the management of Madurese corn farming with regard to cooperation in working on agricultural land. This can be used as the basis for technical policies for realizing the social potential of the community in order to maximize agricultural yields. SES sees this as part of the Governance and Access process. At this point, the use of social resources in agriculture is part of local knowledge which is taken into consideration in decision making (Poe, Norman and Levin 2014).

The government, through the Ministry of Agriculture, is pushing to increase Madura corn production. (Anon n.d.). The policy can be formulated as follows: first, a policy should be made to serve as a technical guideline for the existing policies on agricultural counselors. Agricultural counselors are not only required to have expertise in agricultural management techniques, but they should have expertise in promoting and building up the community participation to play an active role in farmer groups, especially in the 'saleng abentho' tradition.

Second, a policy should be made to institutionalize the potential local social institutions. In its implementation, public awareness is needed to build synergy with the government in accordance with their respective capacities. Third, a policy should be made to manage agricultural conflicts by taking advantage of solidarity and good social ties/cohesion within the community.

\section{CONCLUSIONS \\ RECOMMENDATIONS}

AND

Madurese corn farming requires a social touch as an effort to boost Madurese corn farming. Madura corn farming in Gapurana Village, Talango Sub-district of Sumenep Regency has been going on for generations. The informants interviewed in the field have been farming for 15-20 years, on average. Agricultural techniques are traditional in nature, but the communities adopt a mutual cooperation system, a kind of social gathering. The local 
communities call it as 'saleng abentho' in corn farming. The values and attitudes of mutual cooperation can be used by the community to reduce the costs of Madurese corn farming in Gapurana Village. As a comparison, the cost of corn farming with the 'saleng abentho' model on land of a size equal to $3 \mathrm{~kg}$ of seeds (the local people measure the land area using the unit of seed planting capacity) is IDR 760,000.00. Meanwhile, the cost of farming with the individual model is around IDR 1,690,000.00.

The 'saleng abentho' system in Madurese corn farming is expected to be used as a farming management model to reduce costs. This model can be used along with the role of agricultural assistance through farmer groups. The role of government through local social institutions is very important in its implementation. Future studies can examine the 'saleng abentho' corn farming model from the perspective of agricultural science as a technical analysis. Meanwhile, from an economic perspective, the effectiveness of the 'saleng abentho' model can be investigated comprehensively.

\section{References}

Aminah, S., Lubis, D., \& Susanto, D. (2015). Strategi peningkatan keberdayaan petani kecil menuju ketahanan pangan. Sosiohumaniora, 17(3). Available at:

http://journal.unpad.ac.id/sosiohu maniora/article/view/8343.
Berkes, F., \& Folke, C. (1994). Linking social and ecological systems for resilience and sustainability, dlc.dlib.indiana.edu. Available at: http://dlc.dlib.indiana.edu/dlc/han dle/10535/4352.

Budiarti, T., \& Muflikhati, I. (2013). Pengembangan Agrowisata Berbasis Masyarakat pada Usahatani Terpadu guna Meningkatkan Kesejahteraan Petani dan Keberlanjutan Sistem Pertanian. Jurnal Ilmu Pertanian Indonesia. Available at: https://jurnal.ipb.ac.id/index.php/J IPI/article/view/8398.

Burhan, B. (2007). Penelitian Kualitatif: Komunikasi, Ekonomi, Kebijakan Publik, dan IImu Sosial Lainnya. Jakarta: Prenada Media Group.

Cioffi-Revilla, C. (2016). SocioEcological Systems. Available at: https://www.researchgate.net/prof ile/Claudio-

Cioffi/publication/304195274_Soc io-

Ecological_Systems/links/57d08a 6908ae6399a389dcea/SocioEcological-Systems.pdf.

Cote, M., \& Nightingale, A. J. (2012). Resilience thinking meets social theory: situating social change in socio-ecological systems (SES) research. Progress in human geography. Available at: https://journals.sagepub.com/doi/ abs/10.1177/0309132511425708.

Creswell, J. W., \& Creswell, J. D. (2017). Research design: Qualitative, quantitative, and mixed methods approaches. Available at: http://www.drbrambedkarcollege.

Jurnal IImu Sosial dan Humaniora | 500 
ac.in/sites/default/files/researchdesign-ceil.pdf.

Domptail, S., \& Easdale, M. H. (2013). Managing socio-ecological systems to achieve sustainability: A study of resilience and robustness. Environmental Policy. Available at: https://onlinelibrary.wiley.com/doi/ abs/10.1002/eet.1604.

Fahriyah, F., \& Salma, M. N. D. (2012). Analisis Efisiensi Biaya Dan Keuntungan Pada Usahatani Jagung (Zea Mays) Di Desa Kramat, Kecamatan Bangkalan, Kabupaten Bangkalan, Madura. Agricultural Socio-Economics Journal. Available at: https://agrise.ub.ac.id/index.php/a grise/article/view/80.

Fauziyah, E., Hartoyo, S., \& Kusnadi, N. (2010). Analisis produktivitas usahatani tembakau di kabupaten Pamekasan. Jurnal Organisasi. Available at: http://jurnal.ut.ac.id/index.php/JO M/article/view/287.

Filatova, T, Verburg, P. H., \& Parker, D.C. (2013). Spatial agent-based models for socio-ecological systems: Challenges and prospects. Modelling \& software. Available at: https://www.sciencedirect.com/sci ence/article/pii/S1364815213000 807.

Filatova, Tatiana, Verburg, P. H., Parker, D. C., \& Stannard, C.A. (2013). Spatial agent-based models for socio-ecological systems: Challenges and prospects. Environmental Modelling and Software, 45: 1-7.
Available at: http://dx.doi.org/10.1016/j.envsoft. 2013.03.017.

Firdaus, M. W., \& Fauziyah, E. (2020). Efisiensi Ekonomi Usahatani Jagung Hibrida. Agrisience, 1(1): 74-87.

Hefni, M. (2008). Local knowledge masyarakat Madura: sebuah strategi pemanfaatan ekologi tegal di Madura. KARSA: Jurnal Sosial dan Budaya Keislaman. Available at:

http://ejournal.iainmadura.ac.id/in dex.php/karsa/article/view/121.

Hijjang, P., Lampe, M., \& Basir, M. (2014). Aneka ragam pengetahuan lokal dan kreatifitas petani yang mendukung agroecopreneuer ramah lingkungan di Sulawesi Selatan. Sosiohumaniora. Available at: http://jurnal.unpad.ac.id/sosiohum aniora/article/download/5726/303 9.

Ife, J., \& Tesoriero, F. (2008). Community development: Alternatif pengembangan masyarakat di era globalisasi. Yogyakarta: Pustaka Pelajar.

Kasem, S., \& Thapa, G. B. (2012). Sustainable development policies and achievements in the context of the agriculture sector in Thailand. Sustainable Development. Available at: https://onlinelibrary.wiley.com/doi/ abs/10.1002/sd.467.

Kementerian Pertanian. (2021). Pemerintah Dorong Petani Madura Tanam Jagung Hibrida," Available at: https://www.pertanian.go.id/home 
/?show=news\&act=view\&id=3663 [Accessed October 13, 2021].

Krisnawati, K. (2014). Fungsi Kelompok Tani: Meningkatkan Partisipasi Petani. Sosio Informa. Available at:

http://ejournal.kemensos.go.id/ind ex.php/Sosioinforma/article/view/ 100.

Maleksaeidi, H., \& Karami, E. (2013). Social-ecological resilience and sustainable agriculture under water scarcity. Agroecology and sustainable food. Available at: https://www.tandfonline.com/doi/a bs/10.1080/10440046.2012.7467 67.

Matyja, M. (2016). Resources based factors of competitiveness of agricultural enterprises. Management. Available at: https://search.proquest.com/open view/500c3a22c2fbffae1eefb0893 ea44cf8/1?pqorigsite $=$ gscholar $\&$ cbl $=2026595$.

Micheels, E. T., \& Nolan, J. F. (2016). Examining the effects of absorptive capacity and social capital on the adoption of agricultural innovations: A Canadian Prairie case study. Agricultural Systems. Available at: https://www.sciencedirect.com/sci ence/article/pii/S0308521X16300 506.

Minah, S., Norjietta, T., Rosliah, K., \& Novi, S. K. I. (2019). Local wisdom in agriculture for environmental sustainability: A case study of the Dusun community. International Journal of Innovation, Creativity and Change, 6(8): 117-138.
Mink, S. D., \& Dorosh, P. A. (2019). An Overview of Corn Production. The Corn Economy of Indonesia. Available at: https://www.degruyter.com/docu ment/doi/10.7591/978150174634 5-005/html.

Moleong, L. J. (2000). Metodologi Penelitian Kualitatif, Cetakan XI. Bandung: PT Remaja Rosdakarya.

Parma, P. G. (2014). Pengembangan Model Penguatan Lembaga Pertanian sebagai Prime Mover Pembangunan Kawasan Daerah Penyangga Pembangunan (DPP) Destinasi Wisata. Jurnal IImu Sosial dan Humaniora, 3(1).

Petrosillo, I., Aretano, R., \& Zurlini, G. (2015). Socioecological systems. Reference Module in Earth Systems and Environmental Sciences: 1-7.

Poe, M. R., Norman, K. C., \& Levin, P.S. (2014). Cultural dimensions of socioecological systems: Key connections and guiding principles for conservation in coastal environments. Conservation Letters, 7(3): 166-175.

Purwanto, S. (2007). Perkembangan produksi dan kebijakan dalam peningkatan produksi jagung. Di dalam: Jagung: Teknik Produksi. Available at: http://balitsereal.litbang.pertanian. go.id/wpcontent/uploads/2016/11/dua.pdf.

Ratna, P. (2011). Analisis Bisnis Jagung Lokal Madura Dalam Perspektif Sistem Agribisnis. Cemara, 8(1): 31-36.

Jurnal IImu Sosial dan Humaniora | 502 
Rounsevell, M. D. A., Robinson, D.T., \& Murray-Rust, D. (2012). From actors to agents in socioecological systems models. Philosophical Transactions of the Royal Society B: Biological Sciences, 367(1586): 259-269.

Rovira-Más, F., Chatterjee, I., \& SáizRubio, V. (2015). The role of GNSS in the navigation strategies of cost-effective agricultural robots. Available at: https://www.sciencedirect.com/sci ence/article/pii/S0168169914003 275.

Salim, A. (2006). Teori dan Paradigma Penelitian Sosial: Buku Sumber untuk Penelitian Kualitatif edisi kedua. Yogyakarta: Tiara Wacana.

Santosa, I. (2014). Pengembangan Masyarakat Berbasis Sumberdaya Lokal. Yogyakarta: Pustaka Pelajar.

Sheng, Y., Zhao, S., \& Nossal, K. (2015). Productivity and farm size in A ustralian agriculture: reinvestigating the returns to scale. Available at: https://onlinelibrary.wiley.com/doi/ abs/10.1111/1467-8489.12063.

Soetomo. (2014). Kesejahteraan dan Upaya Mewujudkannya dalam Perspektif Masyarakat Lokal. Yogyakarta: Pustaka Pelajar.

Sterk, M., Leemput, I. A., \& van de Peeters, E. (2017). How to conceptualize and operationalize resilience in socio-ecological systems? Available at: https://www.sciencedirect.com/sci ence/article/pii/S1877343517300 519.
Sugiarti, T., \& Hayati, M. (2009). Persepsi petani Madura dalam menolak komoditas jagung varietas baru. Jurnal Embryo. Available at: http://pertanian.trunojoyo.ac.id/wp -content/uploads/2012/03/4jurnalJagung.pdf.

Suharto, E. (2009). Kebijakan Sosial Sebagai Kebijakan Publik. Bandung: Alfabeta.

Suprapti, I., Darwanto, D. H., \& Mulyo, J. H. (2014). Efisiensi Produksi Petani Jagung Madura dalam Mempertahankan Keberadaan Jagung Lokal. Available at: https://journal.trunojoyo.ac.id/agri ekonomika/article/view/436.

Suprapti, Isdiana, Dwidjono, H. D. (2014). Efisiensi Produksi Petani Jagung Madura Dalam Mempertahankan Keberadaan Jagung Lokal. Agriekonomika 3(1): 96-107.

Suryana, A., \& Agustian, A. (2014). Analisis daya saing usaha tani jagung di Indonesia, repository.pertanian.go.id.

Available at: http://repository.pertanian.go.id/h andle/123456789/4478.

Todaro, M. P., \& Smith, S. C. (2000). Pembangunan Ekonomi di Dunia Ketiga (Vol. 1). H. Munandar, Penyunt.). Jakarta: Erlangga.

Udemezue, J. C., \& Osegbue, E. G. (2018). Theories and models of agricultural development. Annals of Reviews and Research.

Undang Undang Republik Indonesia Nomor 19 Tahun 2013 Tentang Perlindungan Dan Pemberdayaan Petani, Republik Indonesia.

Jurnal IImu Sosial dan Humaniora | 503 
Usman, H., \& Akbar, P.S. (2008). Metodologi penelitian sosial.

Velasco-Fernández, R. (2017). The pattern of Socio-Ecological Systems,

Yusli, Y. and Fauziyah, E. (2020). Variabel Penentu Dan Efisiensi Teknis Produksi Jagung Lokal Di Madura. Agriscience 1(Bps 2013): p.61-73. Available at: https://journal.trunojoyo.ac.id/agri science/article/view/7591.

Zakaria, A.K. (2011). Kebijakan antisipatif dan strategi penggalangan petani menuju swasembada jagung nasional, Analisis Kebijakan Pertanian. Available at: http://ejurnal.litbang.pertanian.go.i d/index.php/akp/article/view/4197. 